\title{
Late Preterm Birth
}

National Cancer Institute

\section{Source}

National Cancer Institute. Late Preterm Birth. NCI Thesaurus. Code C114092.

Birth when a fetus is between 34 weeks and 0 days through 36 weeks and 6 days gestational age. 